\title{
Evidence for the Presence of a New Class of Teichoic Acid in the Cell Wall of Bacterium NCTC 9742
}

\author{
By W. JOHN ANDERTON AND STEPHEN G. WILKINSON* \\ Department of Chemistry, University of Hull, Hull HU6 $7 R X$
}

(Received 16 October 1979)

\begin{abstract}
The composition of the cell wall of bacterium NCTC 9742, variously known as Chromobacterium iodinum or Pseudomonas iodinum and considered by some to be a species of Brevibacterium or Arthrobacter, has been studied. Walls isolated from cells grown in nutrient broth consisted predominantly of peptidoglycan and a phosphorylated polymer containing D-mannitol, glycerol, pyruvic acid, D-glucose and D-galactosamine. This phosphorus-rich polymer, which was slowly released on treatment of the walls with cold aqueous trichloroacetic acid, is considered to be a new type of teichoic acid. Quantitative analysis and the results of preliminary degradative studies indicated that the main backbone was a poly(mannitol phosphate) chain to which $\beta$-glucopyranosyl substituents and pyruvic acid residues (acetal-linked) were attached. It is suggested that the minor components, glycerophosphate and galactosamine, could form a linkage unit for the covalent attachment of the poly(mannitol phosphate) chain to peptidoglycan. In the walls of cells grown on nutrient agar, it appeared that the phosphorus-rich polymer was partly replaced by another polymer containing galactose and an unidentified component which reacted like a 2-keto-3deoxyaldonic acid in the periodate/thiobarbituric acid test. The taxonomic implications of the cell-wall composition are discussed.
\end{abstract}

\section{INTRODUCTION}

In bacterial taxonomy, the organism represented by strain NCTC 9742 is a vagrant species. The original isolate (Davis, 1939) was identified as a new species of Chromobacterium and named Chromobacterium iodinum, because of its production of a dark purple, crystalline pigment (iodinin). The characterization of iodinin as a phenazine derivative (eventually shown to be 1,6-dihydroxyphenazine 5,10-dioxide) led to suggestions (Tobie, 1945; Gilman, 1953) that the organism should be transferred to the genus Pseudomonas, some typical members of which produce chemically related pigments (e.g. pyocyanin and aeruginosins from Pseudomonas aeruginosa). However, neither genus provides a satisfactory home for an organism that is both non-motile and Gram-positive (though with a tendency to be Gram-variable, particularly in young cultures). These and other properties of the organism (including its pleomorphism and poor fermentative powers) led Sneath (1960) to suggest that it might belong either to the genus Corynebacterium or to the genus Brevibacterium. The latter suggestion has been taken up by other workers, e.g. Herbert et al. (1972) and Gerber (1973). The coryneform connection was accepted by Colwell et al. (1969), but the ultrastructure of the organism and values for the mol \% GC of its DNA [60.2\%, De Ley et al. (1966); 60.9 to $63 \%$, Colwell et al. (1969)] were considered to point to the genus Arthrobacter. Not surprisingly, the organism is still listed in the current edition of Bergey's Manual of Determinative Bacteriology (Sneath, 1974) as Chromobacterium iodinum but as a species incertae sedis.

The organism first came to our attention during a survey of pseudomonads for sensitivity 
to the lytic, bactericidal action of EDTA that characterizes $P$. aeruginosa and closely related species (Wilkinson, 1967). The atypical resistance of ' $P$. iodinum' NCTC 9742 led us to examine the composition of isolated cell walls (Wilkinson, 1968). In the virtual absence of lipid and protein, in the high content of peptidoglycan $(43 \%$ in walls from one batch of cells grown on nutrient agar) and in peptidoglycan composition (components and their molar ratios were: glutamic acid, 1 ; alanine, 2; 2,6-diaminopimelic acid, 1 ; glucosamine, 1 ; muramic acid, 1), the walls were similar to those of many other Gram-positive bacteria. Thus, the chemical data are in accord with the results of the ultrastructural studies carried out by Colwell et al. (1969) which revealed a typically Gram-positive type of cell wall. Additional results on wall composition from our earlier study included a variation in monosaccharide composition with growth conditions, and the presence of a phosphorusrich polymer in the walls. Whereas glucose was the sole neutral monosaccharide in walls from cells grown in nutrient broth, galactose and an unidentified sugar reactive in the thiobarbituric acid test for 2-keto-3-deoxyaldonic acids were also present in the walls from cells grown on nutrient agar. The phosphorus-rich polymer was not a conventional teichoic acid, but appeared to be derived from a hexitol. We now report further on the composition of this material and evidence that it constitutes a new class of teichoic acid.

\section{METHODS}

Materials. 1,4-Anhydro-D-mannitol was prepared by the method of Foster \& Overend (1951) and 1,5anhydro-D-mannitol by the method of Fletcher \& Diehl (1952). Mannitol dehydrogenase (EC 1.1.1.67) isolated from Agaricus bisporus was a gift from Dr R. J. Sturgeon. Alkaline phosphatase (EC 3.1.3.1) was type 1 from calf intestinal mucosa (Sigma). Galactose oxidase (EC 1.1.3.9) was used as the Galactostat reagent (Worthington). Lactate dehydrogenase (EC 1.1.1.27), glycerokinase (EC 2.7.1.30), pyruvate kinase (EC 2.7.1.40), hexokinase (EC 2.7.1.1), glucose oxidase (EC 1.1.3.4), peroxidase (EC 1.11.1.7) and glucose-6-phosphate dehydrogenase (EC 1.1.1.49) were Boehringer products.

Growth of organisms and preparation of cell walls. During initial studies, bacterium NCTC 9742 (obtained as Pseudomonas iodinum) was grown for $24 \mathrm{~h}$ at $37^{\circ} \mathrm{C}$ on nutrient agar (Oxoid). Subsequently, batch cultures (20 l) were grown for $24 \mathrm{~h}$ at 30 or $35^{\circ} \mathrm{C}$ in nutrient broth (Oxoid CM67) with aeration at $201 \mathrm{~min}^{-1}$ and stirring at $300 \mathrm{rev} . \mathrm{min}^{-1}$. Yields of cells were about $90 \mathrm{~g}$ wet wt. Walls were isolated from both types of cell using methods described previously (Wilkinson, 1968).

Extraction and purification of the phosphorus-rich polymer. Several standard treatments for the extraction of phosphorylated polymers from bacteria were applied to the isolated cell walls of bacterium NCTC 9742 . These comprised treatment with (a) $40 \%(\mathrm{w} / \mathrm{v})$ aqueous phenol for $40 \mathrm{~min}$ at 4 or $80{ }^{\circ} \mathrm{C}$ (Coley et al., 1975), (b) dimethyl sulphoxide for $4 \mathrm{~h}$ at $60{ }^{\circ} \mathrm{C}$ (Adams, 1967), (c) $2 \%$ (v/v) $N, N$-dimethylhydrazine for $2 \mathrm{~h}$ at $80{ }^{\circ} \mathrm{C}$ (Anderson et al., 1969), (d) $10 \%(\mathrm{w} / \mathrm{v})$ aqueous trichloroacetic acid for various periods at $4{ }^{\circ} \mathrm{C}$ (Wilkinson, 1968). When treatment $(d)$ was used, trichloroacetic acid was subsequently removed by repeated extraction with diethyl ether or $n$-butyl acetate (Young, 1964), and the wall polymer was purified by dialysis or gel permeation chromatography. In the procedure finally adopted, the walls were treated repeatedly $(5 \times 1 \mathrm{~d}, 1 \times 3 \mathrm{~d})$ with aqueous trichloroacetic acid (about $80 \mathrm{ml}$ per $\mathrm{g}$ walls). After each treatment, the wall residues were collected by centrifugation at $4{ }^{\circ} \mathrm{C}$ and $20000 \mathrm{~g}$ for $30 \mathrm{~min}$. Each aqueous supernatant was extracted six times with equal volumes of diethyl ether, carefully neutralized with dilute aqueous ammonia, and freeze-dried. The individual products were separately purified by chromatography on a column of Sephadex G-25 with pyridine/acetic acid/water (10:4:986, by vol.) pH 5.4 as the eluant.

Paper chromatography and electrophoresis. Separations were carried out on Whatman no. 1 or 3MM paper (water-washed for preparative work). Solvent systems used for chromatography were as follows: A, the upper phase of ethyl acetate/pyridine/water $(5: 2: 5$, by vol.); B, the upper phase of ethyl acetate/acetic $\mathrm{acid} /$ water $(3: 1: 3$, by vol. $)$; $\mathrm{C}$, the upper phase of butan-1-ol/ethanol/water/18 M-ammonia (40:10:49:1, by vol.); D, propan-1-ol/18 $\mathrm{M}$-ammonia/water $(6: 3: 1$, by vol.); E, propan-2-ol/5\% (w/v) aqueous boric acid $(7: 1$, by vol.). Buffer systems used for high-voltage electrophoresis were as follows: $F$, pyridine/acetic acid/water $(5: 2: 43$, by vol.) $\mathrm{pH} 5 \cdot 3 ; \mathrm{G}$, pyridine/formic acid/acetic acid/water $(2: 3: 20: 180$, by vol.) pH $2.8 ; \mathrm{H}$, pyridine/acetic acid/water $(1: 10: 89$, by vol.) adjusted to $\mathrm{pH} 2.7$ with formic acid (Kosakai \& Yosizawa, 1975); I, 0.114 M-molybdate buffer pH 5.0 (Mayer \& Westphal, 1968). Reagents used for the detection of amino compounds, phosphate esters, neutral sugars and polyols were those described previously (Wilkinson, 1968).

Thin-layer chromatography (t.l.c.). Chromatography on silica gel $60 \mathrm{~F}_{254}$ (Merck) in solvent system J, 
toluene/acetic acid/water (4:3:1, by vol.), was used to identify the 2,4-dinitrophenylhydrazone of pyruvic acid (Dutton \& Yang, 1973).

Gas-liquid chromatography (g.l.c.). Column packings and operating temperatures used were as follows: I, $10 \%(\mathrm{w} / \mathrm{w})$ diethylene glycol succinate on Chromosorb P $(60$ to $80 \mathrm{mesh}), 180{ }^{\circ} \mathrm{C} ; \mathrm{II}, 3 \%$ (w/w) SE 52 on Celite (60 to $80 \mathrm{mesh}), 170{ }^{\circ} \mathrm{C}$; III, $10 \%$ (w/w) neopentyl glycol sebacate on Celite (60 to $80 \mathrm{mesh}$ ), $220^{\circ} \mathrm{C}$; IV, $15 \%$ (w/w) Apiezon M on Celite (60 to $\left.80 \mathrm{mesh}\right), 200{ }^{\circ} \mathrm{C} ; \mathrm{V}, 3 \%(\mathrm{w} / \mathrm{w})$ ECNSS-M on Gas Chrom Q (100 to 120 mesh), $170^{\circ} \mathrm{C}$; VI, $3 \%$ (w/w) Silar $10 \mathrm{c}$ on Gas Chrom Q (100 to $120 \mathrm{mesh}$ ), $200^{\circ} \mathrm{C}$; VII, $30 \%$ (w/w) SE 52 on Gas Chrom Q (80 to $100 \mathrm{mesh}), 120^{\circ} \mathrm{C}$; VIII, $3 \%$ (w/w) OV 225 on Gas Chrom $\mathrm{Q}$ (100 to $120 \mathrm{mesh}), 109^{\circ} \mathrm{C}$.

Hydrolysis conditions. For the determination of amino compounds, samples were hydrolysed with $6 \cdot 1 \mathrm{M}-$ $\mathrm{HCl}$ at $105^{\circ} \mathrm{C}$ for $4 \mathrm{~h}$ (for amino sugars) or $16 \mathrm{~h}$ (for amino acids). Neutral sugars were released by hydrolysis with $2 \mathrm{M}-\mathrm{HCl}$ at $105{ }^{\circ} \mathrm{C}$ for $2 \mathrm{~h}$. Hydrolyses were also carried out with $1 \mathrm{M}-\mathrm{HCl}$ at $105{ }^{\circ} \mathrm{C}$ for $1 \mathrm{~h}$ (for the detection of uronic acids) or $4 \mathrm{~h}$ (for the release of pyruvic acid). Conditions used for the study of phosphate esters were hydrolysis at $105^{\circ} \mathrm{C}$ for $3 \mathrm{~h}$ with $2 \mathrm{M}-\mathrm{HCl}$ or $1 \mathrm{M}-\mathrm{NaOH}$. The enzymic hydrolysis of phosphomonoesters involved treatment with alkaline phosphatase in $0.05 \mathrm{M}-\left(\mathrm{NH}_{4}\right)_{2} \mathrm{CO}_{3}, \mathrm{pH} 9 \cdot 6$, at $37^{\circ} \mathrm{C}$ for $16 \mathrm{~h}$ under toluene.

Quantitative assays. Phosphorus was determined either by the method of Allen (1940) or by the method of Bartlett (1959). Total carbohydrate was determined by the phenol $/ \mathrm{H}_{2} \mathrm{SO}_{4}$ method (Dubois et al., 1956) with glucose as the standard. D-Glucose was determined by using test combinations (Boehringer) of glucose oxidase/peroxidase or hexokinase/glucose-6-phosphate dehydrogenase. Glycerol was determined by using the combination glycerokinase/pyruvate kinase/lactate dehydrogenase (Boehringer), and D-mannitol by using mannitol dehydrogenase (Sturgeon, 1978). Both glycerol and mannitol were also determined by g.l.c. of their acetate esters. Pyruvic acid was determined by the lactate dehydrogenase method (Boehringer), hexuronic acid by the carbazole method (Bitter \& Muir, 1962) and 3-deoxyoctulosonic acid by the thiobarbituric acid method (Osborn, 1963). Amino compounds were identified and determined by using a Locarte autoanalyser.

Other methods. Polyols were converted into their peracetates by treatment with acetic anhydride/pyridine $(1: 1, \mathrm{v} / \mathrm{v})$ at $100{ }^{\circ} \mathrm{C}$ for $1 \mathrm{~h}$, and into their pertrimethylsilyl ethers by treatment with $N, O$-bis(trimethylsilyl)acetamide $/ N, N$-dimethylformamide $(2: 3, \mathrm{v} / \mathrm{v})$ at room temperature. Pyruvic acid was converted into its $O$-(trimethylsilyl)quinoxalinol derivative as described by Cree et al. (1979). Infrared spectra of samples dispersed in $\mathrm{KCl}$ were recorded with a Unicam SP200 spectrophotometer. Proton magnetic resonance spectra of samples in $\mathrm{D}_{2} \mathrm{O}$ with acetone as the internal standard were recorded with a Jeol $60 \mathrm{MHz}$ spectrometer: spectra at $220 \mathrm{MHz}$ were recorded by the Physico-Chemical Measurements Unit, Harwell, Oxon.

\section{RESULTS}

\section{Cell-wall composition}

In the original studies (Wilkinson, 1968), walls were isolated from two batches of cells grown on nutrient agar. The two batches were qualitatively similar in composition. Both were rich in peptidoglycan but contained little or no protein or lipid. They differed in their contents of phosphorus and carbohydrate. In the first batch (phosphorus $3.07 \%$ ), glucose predominated over galactose, whereas in the second batch (phosphorus $1.67 \%$ ) the proportions of the monosaccharides were reversed. Analyses of a third batch of walls from agar-grown cells (phosphorus $1.71 \%$; carbohydrate $15.1 \%$, mainly galactose) were very similar to those of the second batch. The apparent 3-deoxyoctulosonic acid content of the third batch of walls $(6.2 \%)$ was considerably greater than that of the first batch $(2.0 \%)$. The impression gained from these results was that the walls contained two different carbohydrates, one rich in phosphorus and glucose, the other rich in galactose and an unidentified component reactive in the periodate/thiobarbituric acid test for 3-deoxyoctulosonic acid. Both carbohydrates were apparently extracted from the walls by treatment with trichloroacetic acid (Wilkinson, 1968). Results obtained during studies of the walls from broth-grown cells have reinforced and amplified these conclusions.

In six batches of walls from broth-grown cells, the phosphorus content ranged from 2.32 to $2.54 \%$ (average $2.43 \%$ ) and the carbohydrate content from 5.5 to $6.9 \%$ (average $6.2 \%$ ). Glucose was the only neutral monosaccharide component, and no reaction was obtained in the periodate/thiobarbituric acid test. Thus, the walls apparently contained 


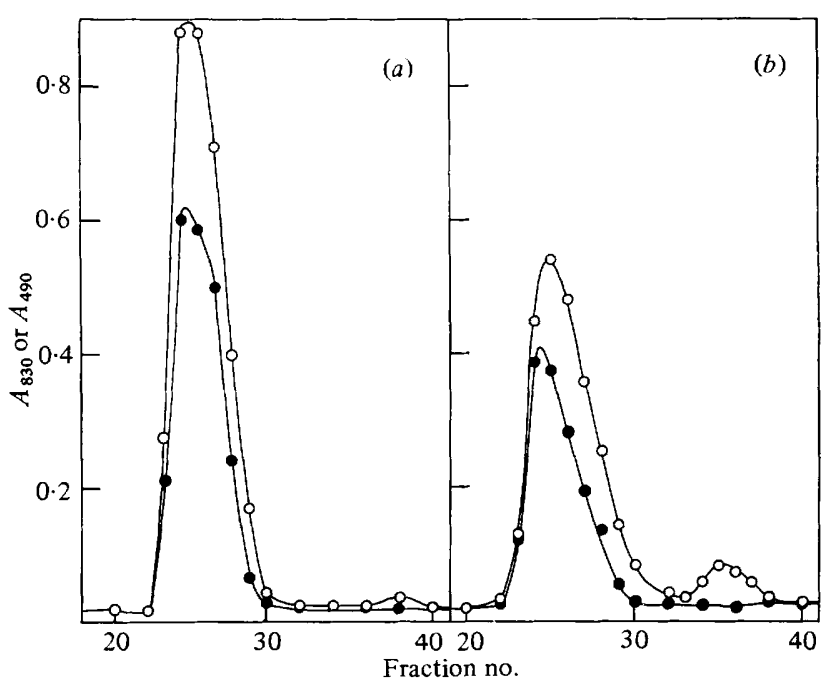

Fig. 1. Gel permeation chromatography of the phosphorus-rich wall polymer. Materials extracted from isolated walls by treatments with $10 \%(\mathrm{w} / \mathrm{v})$ trichloroacetic acid at $4{ }^{\circ} \mathrm{C}$ were applied to a column $(2 \times 90 \mathrm{~cm})$ of Sephadex G-25 (fine). Elution was carried out with pyridine/acetic acid/water (10:4:986, by vol.) $\mathrm{pH} 5 \cdot 4$ at a flow rate of $20 \mathrm{ml} \mathrm{h}^{-1}$. Fractions $(4 \mathrm{ml})$ were analysed for phosphorus $\left(\mathrm{O}, A_{830}\right)$ and carbohydrate $\left(\Theta, A_{490}\right)$. Results are shown for the materials from $(a)$ the second of five $1 \mathrm{~d}$ treatments, $(b)$ a final $3 \mathrm{~d}$ treatment.

only one of the carbohydrate polymers found in the walls of agar-grown cells. Both types of wall had a similar peptidoglycan content (32 to $46 \%$ ) and an identical peptidoglycan composition (glutamic acid/alanine/2,6-diaminopimelic acid/glucosamine/muramic acid in the molar ratio $1: 2: 1: 1: 1$ ). Galactosamine was a minor component of both types of wall (content about $1 \%$ ).

\section{Isolation of the phosphorus-rich wall polymer}

Because the walls from cells grown in liquid culture were available in relatively large amounts, and lacked the galactose-containing carbohydrate, they were used for the isolation and study of the phosphorus-rich polymer. The earlier studies (Wilkinson, 1968) had shown that this polymer was slowly released on treatment of the walls with cold $10 \%(\mathrm{w} / \mathrm{v})$ trichloroacetic acid. In the present work, the extent of the release varied from 52 to $86 \%$ of the available phosphorus in treatments lasting 7 or $8 \mathrm{~d}$. In the most efficient case, in which the walls were extracted four times $(2 \times 1 \mathrm{~d}, 2 \times 3 \mathrm{~d})$, the accumulated release of phosphorus was as follows: $1 \mathrm{~d}, 33 \% ; 2 \mathrm{~d}, 54 \% ; 5 \mathrm{~d}, 78 \% ; 8 \mathrm{~d}, 86 \%$.

Various methods for recovering the phosphorus-rich polymer from the extracts were tried. Because the polymer was not precipitated by the addition of acetone ( 4 vol.) or ethanol $(4 \mathrm{vol}$.$) to the aqueous solutions, trichloroacetic acid was removed by repeated$ extraction with $n$-butyl acetate (no phosphorus was lost in the process). The aqueous solutions were then neutralized, dialysed and freeze-dried. However, variable and sometimes serious losses of phosphorus (12 to $72 \%$ ) occurred during dialysis. To minimize the hydrolytic formation and subsequent loss of low molecular weight products, individual treatments with trichloroacetic acid were limited to $1 \mathrm{~d}$ (except for the final treatment), diethyl ether was used in place of $n$-butyl acetate (with which separation of the two phases was slow) and dialysis was replaced by gel permeation chromatography.

Before this modified procedure was adopted, alternative and potentially milder methods of extraction were tried. No phosphorus was extracted by treatment of the walls with either hot or cold aqueous phenol, and only $10 \%$ by treatment with hot dimethyl sulph- 
oxide. Although the solubilization of wall phosphorus with aqueous $N, N$-dimethylhydrazine was extensive $(81 \%)$, chromatography of the extract on DEAE-cellulose gave two overlapping peaks for phosphorus-containing materials.

Careful treatment of the walls with cold aqueous trichloroacetic acid was therefore the extraction method of choice. The materials present in the extracts from successive treatments had similar chromatographic properties on Sephadex G-25. The bulk of the material was only slightly retarded by the gel, and the elution profiles for phosphorus and carbohydrate were in good agreement. The peaks for polymeric material showed little evidence of tailing, and even in late extracts the amount of low molecular weight material was relatively small (Fig. 1).

\section{Composition of the phosphorus-rich wall polymer}

The phosphorus content of different preparations was generally in the range 6 to $7 \%$, and the carbohydrate content in the range 15 to $21 \%$ (expressed as glucose). On the assumption that the polymer was the sole source of phosphorus and carbohydrate, it accounted for 30 to $40 \%$ of the dry weight of the wall.

D-Glucose (identified by paper chromatography with solvent systems A, B and C, and by positive reactions in the glucose oxidase and hexokinase assays) was the sole neutral monosaccharide present in the polymer, but it accounted for only about one-half of the total carbohydrate as determined by the phenol $/ \mathrm{H}_{2} \mathrm{SO}_{4}$ method with unhydrolysed polymer. However, the reaction products from the latter estimation had $\lambda_{\max } 480 \mathrm{~nm}$, compared with $486 \mathrm{~nm}$ for a glucose standard. With hydrolysates, a discrepancy between the values for glucose and total carbohydrate was found when neutralization was carried out with dilute alkali, but not when Dowex 1 resin $\left(\mathrm{HCO}_{3}{ }^{-}\right.$form $)$was used. These observations, and the appearance of a carbonyl band at $1720 \mathrm{~cm}^{-1}$ in the infrared spectrum of polymer that had been passed down a column of Dowex 50 resin $\left(\mathrm{H}^{+}\right.$form $)$then redried, suggested the presence of a sugar acid. Although the carbazole assay suggested a uronic acid content of about $2 \%$, the colour produced was a different shade from that given by glucuronic acid, and no uronic acid was detected by paper electrophoresis of hydrolysates (buffer systems $\mathrm{F}$ and $\mathrm{H}$ ). Further studies of alkali-neutralized hydrolysates showed that the above results could be attributed to the presence of pyruvic acid. The product isolated by preparative paper electrophoresis had properties identical with those of the reference compound in the following tests: $(a)$ the colour $\left(\lambda_{\max } 475 \mathrm{~nm}\right)$ produced in the phenol $/ \mathrm{H}_{2} \mathrm{SO}_{4}$ reaction; $(b)$ the reduction of alkaline $\mathrm{AgNO}_{3}$ and the production of a light yellow colour (with white fluorescence under ultraviolet light) on heating an electrophoretogram treated with aniline hydrogen oxalate; $(c)$ electrophoretic mobility at $\mathrm{pH} 5 \cdot 3\left(m_{\mathrm{Glc}_{\mathrm{A}}} 2 \cdot 0\right)$ and $\mathrm{pH} 2.8$ $\left(m_{\mathrm{GlcUA}} 3 \cdot 1\right) ;(d)$ a positive reaction in the lactate dehydrogenase assay; $(e)$ t.l.c. of the 2,4-dinitrophenylhydrazone in solvent system $\mathrm{J} ;(f)$ g.l.c. of the $O$-(trimethylsilyl)quinoxalinol derivative on column VIII.

The proton magnetic resonance spectrum of the polymer contained a prominent, sharp singlet at $\delta 1.62$ p.p.m., as expected for an acetal-linked pyruvate residue (e.g. Bebault et al., 1973; Lindberg et al., 1979). Further evidence for an acetal rather than an ester linkage was the absence of a carbonyl absorption at $1720 \mathrm{~cm}^{-1}$ from the infrared spectrum of polymer that had been passed down a column of Dowex 50 resin $\left(\mathrm{Na}^{+}\right.$form), and the marked difference in complexity between the mixture of phosphate esters produced on acid hydrolysis of the polymer and that produced on alkaline hydrolysis (see below). The results of enzymic assays for pyruvic acid and glucose in one batch of polymer (Table 1) indicated that these components accounted for about $90 \%$ of the phenol $/ \mathrm{H}_{2} \mathrm{SO}_{4}$ reactivity and were present in a molar ratio of $2: 1$. This was supported by the relative intensity (about $6: 1$ ) of the signals in the proton magnetic resonance spectrum for the pyruvate methyl group ( $\delta 1.62$ p.p.m.) and the anomeric proton(s) $\left(\delta 4.68\right.$ p.p.m., $J_{1,2} 9 \mathrm{~Hz}$, attributable to a $\beta$-D-glucopyranosyl group). 
Table 1. Quantitative analysis of the phosphorus-rich wall polymer

Component

Phosphorus
Total carbohydrate
D-Glucose
D-Galactosamine
Pyruvic acid
Glycerol
D-Mannitol

Percentage of dry weight of polymer

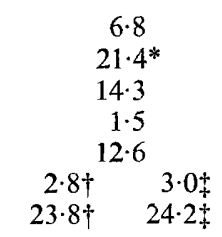

\footnotetext{
* Determined as glucose by the phenol $/ \mathrm{H}_{2} \mathrm{SO}_{4}$ method. $\dagger$ Determined by gas-liquid chromatography.

+ Determined by enzymic assay.
}

Paper chromatography (solvent systems A, B, D and E) of deionized acid hydrolysates revealed the presence not only of glucose, but of components with the mobilities and reactions of glycerol, mannitol and 1,4-anhydromannitol (but no 1,5-anhydromannitol). 1,4-Anhydromannitol was readily detected by means of the strong yellow colour given with the periodate/Schiff reagents (Hardy \& Buchanan, 1963). Much larger amounts of the polyols were obtained when an acid hydrolysate of the polymer (dried repeatedly over $\mathrm{P}_{2} \mathrm{O}_{5}$ and $\mathrm{KOH}$ ) was treated with alkaline phosphatase. The acid hydrolysate was separated into monophosphate and diphosphate fractions by paper chromatography in solvent $\mathrm{D}$. Phosphatase action on both of these fractions yielded glycerol and mannitol but only the monophosphate fraction also gave rise to 1,4-anhydromannitol. All three polyols were also released by alkaline phosphatase treatment of the mixture of phosphate esters produced by alkaline hydrolysis of the polymer. The following additional methods were used to confirm the identities of the polyols obtained by one means or another. Glycerol was identified by $(a)$ paper electrophoresis (buffer system I), $(b)$ g.l.c. of its acetate ester (column VII) and (c) enzymic assay. Mannitol was identified by $(a)$ paper electrophoresis (buffer system I), (b) g.l.c. of its acetate ester (columns III, IV, V and VI), (c) g.l.c. of its trimethylsilyl ether (columns I and II) and (d) enzymic assay with mannitol dehydrogenase (which also confirmed the D configuration). 1,4-Anhydromannitol was also identified by g.l.c. of its acetate ester (columns V and VI).

Whereas the action of alkaline phosphatase on the mixtures of phosphate esters present in acid and alkaline hydrolysates of the polymer led to essentially complete release of inorganic orthophosphate, less than $1 \%$ of the phosphorus present in the intact polymer was released by such treatment. Gel permeation chromatography and paper electrophoresis confirmed that alkaline (as well as acid) hydrolysis caused depolymerization of the wall material, which indicated the involvement of phosphodiester linkages. Paper chromatography (solvent system D) and electrophoresis (buffer system F), as well as the results of alkaline phosphatase treatment discussed above, indicated that polyol monophosphates and diphosphates were the major components of acid hydrolysates. Such phosphate esters were, however, only minor products in alkaline hydrolysates. By means of DEAE-cellulose chromatography and preparative paper electrophoresis, some nine phosphorus-containing fractions were isolated from an alkaline hydrolysate. This proliferation of components can be attributed to the effects of glucosyl and pyruvate substitution on the course of hydrolysis and on the variable presence of the substituents in the final products. Analysis confirmed that all of the glucose was alkali-stable.

The last component of the polymer to be identified was galactosamine. As acid hydrolysates also gave a positive reaction with galactose oxidase but did not contain galactose, it appeared that the hexosamine had the D configuration (Sempere et al., 1965). Quantitative 
analyses for this and other components of the polymer, all obtained for the same batch, are summarized in Table 1.

\section{DISCUSSION}

The present results and those of the earlier study (Wilkinson, 1968) show that the major components of the cell wall of bacterium NCTC 9742 are peptidoglycan and one or both of two carbohydrate-containing polymers, both of which can be extracted with cold $10 \%$ $(\mathrm{w} / \mathrm{v})$ trichloroacetic acid. Whereas the phosphorus-rich polymer was present in the walls of cells from both surface and liquid cultures, the second polymer which apparently contained galactose and a 2-keto-3-deoxyaldonic acid was only present in the walls from surface cultures. It seems very likely that the second polymer is produced as a response to phosphorus limitation of growth. Such a response would be entirely analogous to the replacement of the wall teichoic acid by a teichuronic acid during the growth of other Gram-positive species under phosphorus-limited growth conditions (Ellwood \& Tempest, 1972).

The main concern of the present study was to optimize conditions for the isolation of the phosphorus-rich polymer, and to identify and estimate its components. To the best of our knowledge, no wall polymer of similar composition has previously been obtained from a Gram-positive organism. Nevertheless, in a number of its compositional and structural features the material resembles a teichoic acid. Its novel features include the presence of D-mannitol and pyruvic acid, neither of which is found in conventional teichoic acids (Duckworth, 1977). Although detailed structural studies have yet to be completed, it seems likely that the main backbone of the polymer consists of a poly(mannitol phosphate) chain to which glucosyl substituents and acetal-linked pyruvic acid residues are attached. The approximate molar ratio for mannitol/glucose/pyruvic acid of $2: 1: 2$ shows that not all mannitol residues could carry glucosyl substituents and indicates that the pyruvic acid is more likely to be attached to mannitol than to glucose.

The slow extraction of the polymer from the cell walls with trichloroacetic acid suggests that extraction involves the cleavage of a covalent linkage from the polymer to the insoluble peptidoglycan. It is therefore tempting to suggest that the glycerophosphate and galactosamine residues in the polymer constitute a linkage unit. In several Gram-positive organisms, the units that link the wall teichoic acid to peptidoglycan have been shown to contain tri(glycerol phosphate) and glucosamine residues (Coley et al., 1978).

Because the phosphorus-rich polymer isolated from bacterium NCTC 9742 appears to be unique, this study of the cell-wall composition of the organism does not immediately help to establish its taxonomic position or relationships. Nevertheless, cell-wall composition has been used extensively in the classification of coryneform bacteria (Keddie \& Cure, 1978). Both we and Fiedler et al. (1970) have shown that the peptidoglycan of bacterium NCTC 9742 contains glutamic acid, alanine, 2,6-diaminopimelic acid, glucosamine and muramic acid in the molar ratio $1: 2: 1: 1: 1$. Fiedler et al. (1970) also recorded that the diaminopimelic acid was the meso isomer, and studies of our preparation by Dr P. J. White have confirmed this finding. Thus, in peptidoglycan type the organism resembles Corynebacterium sensu stricto and is clearly differentiated from many coryneform organisms, including Arthrobacter globiformis, of which the peptidoglycan is different or more complex in composition (Schleifer \& Kandler, 1972; Keddie \& Cure, 1978). The neutral sugar composition of the cell wall has also proved to be useful in the classification of coryneform organisms. For example, Corynebacterium sensu stricto is considered to demand the presence of both arabinose and galactose. However, the available data (Keddie \& Cure, 1978) and the phenotypic variation encountered in the present study do not help to determine the taxonomic position of ' $P$. iodinum'. Little seems to be known about the possible occurrence of teichoic acids in coryneform organisms (Archibald, 1974; Duckworth, 1977). In several species, e.g. Corynebacterium poinsettiae (Diaz-Mauriño \& Perkins, 1974) and Arthrobacter 
globiformis (Duxbury et al., 1977), the presence of phosphorus in the cell wall was not indicative of a teichoic acid component. Thus, although the results of the present study leave ' $P$. iodinum' in taxonomic limbo, the discovery of the novel mannitol phosphate polymer could eventually prove to be useful in clarifying the situation. It may be relevant to note that mannitol 1-phosphate was isolated from Lactobacillus arabinosus during the course of a study that eventually led to the discovery of the ribitol and glycerol teichoic acids (Baddiley et al., 1956).

W. J. Anderton was supported by a research studentship from the Science Research Council. We thank Dr R. J. Sturgeon of the Department of Brewing and Biological Sciences, Heriot-Watt University for generous gifts and advice in the use of mannitol dehydrogenase, and Dr P. J. White of the Department of Microbiology, University of Sheffield for the identification of meso-2,6-diaminopimelic acid. We are also grateful to Miss P. Kilduff of this department for gas-liquid chromatography.

\section{REFERENCES}

Adams, G. A. (1967). Extraction of lipopolysaccharides from Gram-negative bacteria with dimethyl sulfoxide. Canadian Journal of Biochemistry 45, 422-426.

Allen, R. J. L. (1940). The estimation of phosphorus. Biochemical Journal 34, 858-865.

Anderson, J. C., Archibald, A. R., Baddiley, J., Curtis, M. J. \& DaveY, N. B. (1969). The action of dilute aqueous $N N$-dimethylhydrazine on bacterial cell walls. Biochemical Journal 113, 183-189.

Archibald, A. R. (1974). The structure, biosynthesis and function of teichoic acid. Advances in Microbial Physiology 11, 53-95.

Baddiley, J., Buchanan, J. G., Carss, B., Mathias, A. P. \& Sanderson, A. R. (1956). The isolation of cytidine diphosphate glycerol, cytidine diphosphate ribitol and mannitol 1-phosphate from Lactobacillus arabinosus. Biochemical Journal 64, 599-603.

Bartlett, G. R. (1959). Phosphorus assay in column chromatography. Journal of Biological Chemistry 234, 466-468.

Bebault, G. M., Choy, Y. M., Dutton, G. G. S., FunNell, N., Stephen, A. M. \& YANG, M. T. (1973). Proton magnetic resonance spectroscopy of Klebsiella capsular polysaccharides. Journal of Bacteriology 113, 1345-1347.

BitTer, T. \& Muir, H. M. (1962). A modified uronic acid carbazole reaction. Analytical Biochemistry 4, 330-334.

Coley, J., Duckworth, M. \& Baddiley, J. (1975). Extraction and purification of lipoteichoic acids from Gram-positive bacteria. Carbohydrate Research 40, 41-52.

Coley, J., Tarelli, E., Archibald, A. R. \& BadDILEY, J, (1978). The linkage between teichoic acid and peptidoglycan in bacterial cell walls. FEBS Letters 88, 1-9.

Colwell, R. R., Citarella, R. V., Ryman, I. \& Chapman, G. B. (1969). Properties of Pseudomonas iodinum. Canadian Journal of Microbiology 15, 851-857.

Cree, T. C., Hutson, S. M. \& Harper, A. E.
(1979). Gas-liquid chromatography of $\alpha$-keto acids: quantification of the branched-chain $\alpha$-keto acids from physiological sources. Analytical Biochemistry 92, 156-163.

DAvis, J. G. (1939). Chromobacterium iodinum (n.sp.). Zentralblatt für Bakteriologie, Parasitenkunde, Infektionskrankheiten und Hygiene (Abteilung II) 100, 273-276.

De Ley, J., Park, I. W., Tijtgat, R. \& van ErmenGEM, J. (1966). DNA homology and taxonomy of Pseudomonas and Xanthomonas. Journal of General Microbiology 42, 43-56.

Diaz-Mauriño, T. \& Perkins, H. R. (1974). The presence of acidic polysaccharides and muramic acid phosphate in the walls of Corynebacterium poinsettiae and Corynebacterium betae. Journal of General Microbiology 80, 533-539.

Dubois, M., Gilles, K. A., Hamilton, J. K., Rebers, P. A. \& Smith, F. (1956). Colorimetric method for determination of sugars and related substances. Analytical Chemistry 28, 350-356.

Duckworth, M. (1977). Teichoic acids. In Slirface Carbohydrates of the Prokaryotic Cell, pp. 177208. Edited by I. W. Sutherland. London: Academic Press.

Dutton, G. G. S. \& YANG, M.-T. (1973). The structure of the capsular polysaccharide of Klebsiella K-type 5. Canadian Journal of Chemistry 51, 1826-1832.

Duxbury, T., Gray, T. R. G. \& Sharples, G. P. (1977). Structure and chemistry of walls of rods, cocci and cystites of Arthrobacter globiformis. Journal of General Microbiology 103, 91-99.

Ellwood, D. C. \& Tempest, D. W. (1972). Effects of environment on bacterial wall content and composition. Advances in Microbial Physiology 7, 83-117.

Fiedler, F., Schleifer, K. H., Cziharz, B., InterSCHICK, E. \& KANDLER, O. (1970). Murein types in Arthrobacter, brevibacteria, corynebacteria and microbacteria. Publications de la Faculté des sciences de l'Université J. E. Purkyne, Brno 47, 111-122.

Fletcher, H. G. \& Diehl, H. W. (1952). The 
preparation of 1,5-anhydro-D-mannitol (styracitol) from D-mannitol. Journal of the American Chemical Society 74, 3175-3176.

Foster, A. B. \& Overend, W. G. (1951). Some derivatives of 3:6-anhydromannitol. Journal of the Chemical Society, 680-684.

Gerber, N. N. (1973). Microbial phenazines. In CRC Handbook of Microbiology, vol. III, pp. 329-332. Edited by A. I. Laskin \& H. A. Lechevalier. Cleveland, Ohio: CRC Press.

GilmaN, J. P. (1953). Studies on certain species of bacteria assigned to the genus Chromobacterium. Journal of Bacteriology 65, 48-52.

Hardy, F. E. \& Buchanan, J. G. (1963). The identification of carbohydrates giving derivatives of malonaldehyde on oxidation with sodium periodate. Journal of the Chemical Society, 5881-5885.

Herbert, R. B., Holliman, F. G. \& Ibberson, P. N. (1972). Incorporation of 6-hydroxyphenazine-1-carboxylic acid into iodinin. Journal of the Chemical Society, Chemical Communications, 355356.

Keddie, R. M. \& Cure, G. L. (1978). Cell wall composition of coryneform bacteria. In Coryneform Bacteria, pp. 47-83. Edited by I. J. Bousfield \& A. G. Callely. London: Academic Press.

Kosakai, M. \& Yosizawa, Z. (1975). A rapid method for separation and identification of several hexuronic acids and hexuronic acid-containing oligosaccharides. Analytical Biochemistry 69, 415419.

LindBerg, B., LindH, F., LöNNGRen, J. \& NimMICH, W. (1979). Structural studies of the capsular polysaccharide of Klebsiella type 33. Carbohydrate Research 70, 135-144.

MAYeR, H. \& Westphal, O. (1968). Elektrophoretische Trennungen von Hexosamin- und Hexuronsäurederivaten als Molybdatkomplexe. Journal of Chromatography 33, 514-525.
OsborN, M. J. (1963). Studies on the Gram-negative cell wall. I. Evidence for the role of 2-keto-3deoxyoctonate in the lipopolysaccharide of $\mathrm{Sal}$ monella typhimurium. Proceedings of the National Academy of Sciences of the United States of America 50, 499-506.

SCHLeIfer, K. H. \& Kandler, O. (1972). Peptidoglycan types of bacterial cell walls and their taxonomic implications. Bacteriological Reviews 36, 407-477.

Sempere, J. M., Gancedo, C. \& Asensio, C. (1965). Determination of galactosamine and $\mathrm{N}$-acetylgalactosamine in the presence of other hexosamines with galactose oxidase. Analytical Biochemistry 12, 509-515.

SNEATH, P. H. A. (1960). A study of the bacterial genus Chromobacterium. Iowa State Joutrnal of Science 34, 243-500.

SNEATH, P. H. A. (1974). Genus Chromobacterium Bergonzini. In Bergey's Manual of Determinative Bacteriology, 8th edn, pp. 354-357. Edited by R. E. Buchanan \& N. E. Gibbons. Baltimore: Williams \& Wilkins.

Sturgeon, R. J. (1978). An analytical method for the enzymic estimation of mannitol. In Abstracts of the IXth International Symposium on Carbohydrate Chemistry, pp. 355-356. London: IUPAC.

TobIE, W. C. (1945). A proposed biochemical basis for the genus Pseudomonas. Journal of Bacteriology 49, 459-462.

WILKINSON, S. G. (1967). The sensitivity of pseudomonads to ethylenediaminetetra-acetic acid. Journal of General Microbiology 47, 67-76.

WiLkinson, S. G. (1968). Studies on the cell walls of Pseudomonas species resistant to ethylenediaminetetra-acetic acid. Journal of General Microbiology 54, 195-213.

YounG, D. A. B. (1964). Use of butyl acetate as a solvent for the extraction of trichloroacetic acid. Biochimica et biophysica acta 90, 178-179. 